\title{
Green HRM Practices Followed by Selected Manufacturing Industries in Coimbatore
}

\author{
K. T. Vijaykarthigeyan, A. Giriprakash
}

\begin{abstract}
There is an increasing need for combining environmental management into Human Resource Management (HRM) which the experts termed as "Green HRM ". It is the research practice and Sustainability for any company focuses on its existence in relation to economic and social sustainability of the firm. In the recent era, due to different legal, social, moral, and, ethical issues, it is required to acknowledge that, individual and social responsibility for saving the mother earth is not an optional thing but a business imperative. It is essential for any company/firm to ensure that, recent business goals have made without compromising the ability of future generations for meeting their own needs. To attain the same, 'Green HRM' is emerging as a recent initiative that promotes environment concerned Human Resources practices. Through Green Human Resources practices, firms seek to produce the environmental awareness and commitment for greener world, among employees and society. Green HRM initiatives taken by companies will result in greater efficiency, lower costs and improved employee engagement and retention, with the help of initiatives taken in different HR processes for improving the sustainable utilization of resources. The Greening of Human Resource policies include methods of environmentally friendly "green" initiatives that organizations are utilizing, involving their workforce and human resource practices. The present paper makes an effort for discuss the concept of Green HRM, reviews various studies conducted across globe in the field of Green HRM and analyses the awareness about how the Green HRM has been implemented in the selected manufacturing industries in Coimbatore.
\end{abstract}

Index Terms: HRM, GreenHRM, Sustainability, Greaterefficiency, Greening, Manufacturing industries, Coimbatore.

\section{INTRODUCTION}

In today's rapidly converting globalized business world, sustainability for an business enterprise specializes in organizational existence in terms of monetary, ecological, and social sustainability. Researchers have opined that businesses have to be aware of social and environmental elements along with budget friendly and financial factors so that you can sustain and live on (Govindarajulu \& Daily 2004). Daily and Huang (2001) also opined that organizations essentially need environment in which one lives is nicely preserved and promoted. Green HRM is the concept which promotes sustainable practices via growing employees' awareness and commitments on sustainability. It entails adopting and implementing environment-pleasant HR projects, a good way to attain extra efficiencies, and better employee engagement,

Revised Manuscript Received on July 05, 2019

Dr. K. T. Vijaykarthigeyan, SRM School of Management, SRM Institute of Science and Technology, Kattankulathur, Tamizhnadu, India.

Mr. A. Giriprakash, Coimbatore Institute of Management and Technology, Coimbatore, Tamizhnadu, India to stability the commercial boom and ensuring that the

which in flip, help agencies to reduce worker carbon footprints.

The green control may additionally result in a company's stronger operational overall performance (Jackson et al., 2012), greater teamwork (Jabbour et al., 2010), advanced organizational lifestyle (Jabbour et al., 2012) and reduced cost (Hart 1997). HR practices, being implemented in line with the lifestyle and enterprise approach, need to make a contribution in the direction of organizational performance (Boselie et al, 2001). Thinking about this, researchers supply importance to adoption of environmental practices as a key goal of organizational functioning making it important to discover with the help of human resource management practices (Jackson et.al., 2011; Daily and Hung, 2001; Sarkis et al., 2010). since inexperienced HRM goals to combine HRM methods with organizational techniques of sustainability, it may encompass strict recruitment techniques (Grolleau et al., 2012), appraisal and praise structures linked with the environmental focus and implementation of their assessment method (Jabbour et al,.2012) and training and empowerment programs (Unnikrishnan and Hedge 2007), so that you can enable the development of recent set of competencies and abilities among the personnel of "seasoned-inexperienced" companies (Cherian \& Jacob, 2012).

Environmental Sustainability: Sustainability is frequently defined because the "capability to fulfill the needs of the existing with out compromising the capacity of future generations to satisfy their needs (WCED, 1987 as mentioned in Cohen Toylor \& Muller, 2004). Within the environmental literature, the concept of green control for sustainable development has diverse definitions; all of which commonly, are seeking for to explain the need for balance among business increase for wealth creation and safeguarding the natural environment so that the destiny generations may thrive (Daily \& Huang, 2001). Despite the fact that, the problem of ways an individual company or whole society achieves sustainability from the green human useful resource control motion remains arguable and doubtful. As a result, research on how enterprise may additionally shape their centers to beautify for sustainability through green human aid control projects seems paramount.

\section{REVIEWS OF PREVIOUS STUDIES}

The reason of going green is to use merchandise and methods that would not negatively impact the environment thru pollution or depleting natural sources (Robinson,2008). If the use of natural resources is decreased by using alternative resources, it'll have wonderful consequences

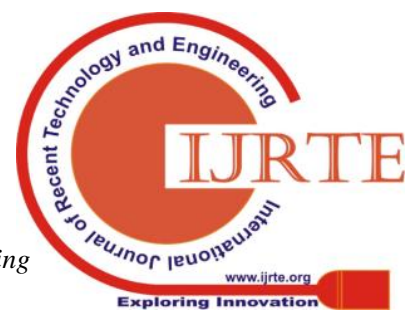


inclusive of keeping the environmental footprint small, lowering waste and re-the usage of materials as a great deal as possible (Dallas, 2008). In addition, it'll result in the use of scarce natural assets efficaciously and correctly, at the same time as retaining the environment loose from unfavorable products.

Researchers on this paper argued that environmental management machine can best be correctly carried out if the organizations have the proper people with the proper abilities and skills (each day and Huang, 2001). Strategic HRM researchers argued that to reap HR effectiveness, HR need to be practiced as a whole and should be aligned with the enterprise strategic dreams, the primary means via which firms can impact and shape the abilities, attitudes, and behavior of individuals to do their paintings and accordingly gain organizational goals (Collins and Clark, 2003). Previously, groups assumed that incorporating 'green' into their commercial enterprise approach might cost money, but they now understand that ignoring bad impacts at the surroundings can be highly-priced in the destiny (Van der Zee, 2008).

The topic of the inexperienced HRM is attracting increased attention among control students. no matter its importance to managers, personnel, clients and other stakeholders, however, there are very few studies studies that don't forget a complete technique of HRM in agencies striving to obtain environmental sustainability. there may be, for that reason, a developing need for the mixing of environmental control into HRM.

\section{A. Research Design}

It is a descriptive research. A questionnaire was prepared. These questions were designed to assess the respondents' perception about the concept of Green HRM, and their awareness about the respective organizations' Green HR initiatives.

\section{B. Sample}

The sample consists of 200 junior and senior executives, working in manufacturing sector of Coimbatore district and utmost care is taken to fill all 200 issued questionnaires. The work experience of those respondents varied between one and 20 years, in the selected industry.

\section{OBJECTIVES OF THE STUDY}

- To find out whether the organization is providing awareness about Green HR Practices among the employees of manufacturing industries in Coimbatore.

- To examine the perception of employees regarding implementation of Green HR Practices in the Organization.

\section{HYPOTHESIS OF THE STUDY}

1. H0: Male and Female has the same level of awareness on the green HR practices practiced by the organisation. H1: Male and Female has different level of awareness on the green HR practices practiced by the organisation.
2. H0: All age group people have the same level of awareness on the green HR practices.

H1: Level of awareness about green HR practices differs with age group.

3. H0: The feeling on E- Selection adopted by the organization for hiring employees does not differ with the employee experience.

H1: The feeling on E- Selection adopted by the organization for hiring employees differs with the employee experience.

\section{RESULTS AND DISCUSSION}

The collected data were analyzed using suitable tools and presented

Table 1: Showing the Mean value and Standard Deviation value of employees opinion on the Green Working Environment.

\begin{tabular}{|l|c|c|}
\hline $\begin{array}{c}\text { Category of Green } \\
\text { Working Environment }\end{array}$ & $\begin{array}{c}\text { Mean } \\
\text { Value }\end{array}$ & $\begin{array}{c}\text { SD } \\
\text { Value }\end{array}$ \\
\hline Comfortable Space & 4.44 & 0.745 \\
\hline Environmental Friendly & 4.35 & 0.938 \\
\hline Formal/Informal Policy & 4.27 & 0.858 \\
\hline Telecommuting & 4.19 & 0.882 \\
\hline Green Suggestion & 3.22 & 1.548 \\
\hline
\end{tabular}

Source: Computed form primary data

Management provides a very comfortable and relaxed space for employees to have their lunch which secures the top rank with a mean score of 4.44. The company encourages employees to work more environmentally friendly which secures second rank with mean score of 4.35. Organization following a formal or informal environment responsibility policy which secures third rank with a mean score of 4.27. The company allows their employees to work at home or telecommuting which secures fourth rank with a mean score of 4.19. The company encourages their employees / workers to participate / give suggestions on green suggestion scheme regarding green HR issues which secures fifth rank with a mean score of 3.22

Table 2: Mean Value and SD Value of the Awareness level of Employees on Green HR Practices: 


\begin{tabular}{|l|c|c|}
\hline Employee Awareness on & $\begin{array}{c}\text { Mean } \\
\text { Value }\end{array}$ & $\begin{array}{c}\text { SD } \\
\text { Value }\end{array}$ \\
\hline Green HR Campaign & 3.62 & 1.079 \\
\hline Recycling Program & 3.99 & 0.896 \\
\hline Green Agenda & 3.47 & 1.368 \\
\hline Energy Conservation & 3.47 & 1.171 \\
\hline Automatic Shutoff & 2.64 & 1.246 \\
\hline
\end{tabular}

\section{SOURCE: COMPUTED FORM PRIMARY DATA}

Management offering recycling programs for office products which is first with a mean score of 3.99. Conducting green HR campaign programs by an organization for its employees to provide awareness about green HR issues secures second rank with a mean score of 3.62. Job description in the corporate website of the company which supports green agenda ranked third with a mean score of 3.47. Energy saving efficient lighting systems and equipment which were used by the management for energy conservation shares the third rank with green agenda. Automatic shutoff is used for equipment by the management for energy conservation has a mean score of 2.64 .

\section{Analysis of Variance}

Analysis is done to find out whether there is any relationship between Age group of employees and their level of awareness regarding Green HR Practices. Green human resources make employees to promote sustainable practices and increase awareness among employees and their commitments on the issues of sustainability. For undertaking environment-friendly HR initiatives like better employee engagement, lower cost, reduction in carbon footprints etc. management should provide awareness programs among employees based on their age because employees outlook or perception regarding green HR practices may vary according to the age of employees.

\section{Hypothesis for age and Employee awareness}

H0: All age group people have the same level of awareness on the green HR practices.

H1: Level of awareness about green HR practices differs with age group.

Table 3: Difference between age and Employee awareness about Green HR Practices

\begin{tabular}{|l|c|c|c|c|c|}
\hline \multirow{4}{*}{$\begin{array}{l}\text { Employee } \\
\text { Awareness }\end{array}$} & $\begin{array}{c}\text { Below } \\
\mathbf{2 5}\end{array}$ & $\mathbf{2 6 - 3 5}$ & $\begin{array}{c}\mathbf{3 6} \text { and } \\
\text { above }\end{array}$ & $\begin{array}{c}\text { F } \\
\text { Value }\end{array}$ & $\begin{array}{c}\text { P } \\
\text { Value }\end{array}$ \\
\cline { 2 - 5 } & $\begin{array}{c}4.60 \\
(1.278)\end{array}$ & $\begin{array}{c}4.29 \\
(0.935)\end{array}$ & $\begin{array}{c}5.00 \\
(0.867)\end{array}$ & 1.945 & 0.125 \\
\hline
\end{tabular}

Since the $\mathrm{P}$ value is 0.125 , Null hypothesis is accepted at $5 \%$ level. Hence it is concluded that, there is no significant difference between age and employee awareness regarding green HR practices. It is clearly stated that employees' age has no influence on the awareness regarding green HR practices because employee awareness is stable and is extremely based on the information which they have gained.

\section{Hypothesis for Genderand Employee awareness}

H0: Male and Female has the same level of awareness on the green HR practices practiced by the organisation.

H1: Male and Female has different level of awareness on the green HR practices practiced by the organisation.

Table 4: Difference between Gender and Employee awareness about Green HR Practices

\begin{tabular}{|c|c|c|c|c|}
\hline \multirow{3}{*}{$\begin{array}{l}\text { Employee } \\
\text { Awareness }\end{array}$} & \multicolumn{2}{|c|}{ Gender } & \multirow{2}{*}{$\begin{array}{c}\text { F } \\
\text { Value }\end{array}$} & \multirow{2}{*}{$\begin{array}{c}\mathbf{P} \\
\text { Value }\end{array}$} \\
\hline & Male & Female & & \\
\hline & $\begin{array}{c}5.32 \\
(1.418)\end{array}$ & $\begin{array}{c}3.859 \\
(0.824)\end{array}$ & 1.482 & 0.175 \\
\hline
\end{tabular}

Since the $\mathrm{P}$ value is 0.175 , Null hypothesis is accepted at $5 \%$ level. Hence it is concluded that, there is no significant difference between gender and employee awareness regarding green HR practices. It is clearly stated that employees' gender has no influence on the awareness regarding green $\mathrm{HR}$ practices because employee awareness is stable irrespective of whether they are male or female and is extremely based on the information which they have gained through their qualification

\section{Hypothesis for employee experience and E- Selection adopted}

H0: The feeling on E- Selection adopted by the organization for hiring employees does not differ with the employee experience.

H1: The feeling on E- Selection adopted by the organization for hiring employees differs with the employee experience.

Table 5: Difference between Experience in Years and Electronic Selection Adopted

\begin{tabular}{|c|c|c|c|c|c|c|}
\hline \multirow{3}{*}{$\begin{array}{c}\text { Electronic } \\
\text { Selection } \\
\text { Adopted }\end{array}$} & \multicolumn{4}{|c|}{ Experience in Years } & \multirow[b]{2}{*}{$\begin{array}{c}\text { F } \\
\text { Value }\end{array}$} & \multirow[b]{2}{*}{$\begin{array}{c}\mathbf{P} \\
\text { Value }\end{array}$} \\
\hline & $\begin{array}{l}\text { Below } \\
\text { 2years }\end{array}$ & $\begin{array}{c}2-5 \\
\text { Years }\end{array}$ & $\begin{array}{c}6-10 \\
\text { years }\end{array}$ & $\begin{array}{c}\text { Above } \\
11 \\
\text { years }\end{array}$ & & \\
\hline & $\begin{array}{c}3.56 \\
(1.456)\end{array}$ & $\begin{array}{c}4.85 \\
(0.985)\end{array}$ & $\begin{array}{c}5.93 \\
(0.854)\end{array}$ & $\begin{array}{c}4.11 \\
(0.756)\end{array}$ & 11.543 & 0.004 \\
\hline
\end{tabular}

SinCE THE P VALUE IS 0.004 , NULL HYPOTHESIS IS REJECTED AT 5\% LEVEL. HENCE IT IS CONCLUDED THAT, THERE IS A SIGNIFICANT DIFFERENCE BETWEEN EXPERIENCE OF THE EMPLOYEES AND E-SELECTION ADOPTED FOR HIRING. IT IS CLEARLY STATED THAT EMPLOYEES EXPERIENCE PLAYS AN ESSENTIAL ROLE IN RECRUITMENT.

\section{SUGGESTIONS OF THE STUDY}

Green Employer: Organization should recruit green Green Employer: Organization should recruit green employer or employees who are aware about green environment and green HR practices. Management should recruit them at right time and at right place. By recruiting green employer, which may improve employer branding as well as staff motivation, employee engagement, increases workforce and reduces employee turnover.

Green Team: Creating green teams among employees will helps to identify green issues and also it provides specific solutions for the problems, this makes organization to operate 
more environmentally sustainable. Such teams will educate, inspire and empower employees regarding green environment and green issues.

Selection: Management should adopt E- selection for hiring employees. It will reduce usage of carbon foot prints and also reduces cost \& time. Management should conduct green orientation programs for newly hired employees; this will create environmental awareness among newly hired employees.

E- Performance Management: For measuring environmental performance of employees organizations should use E- performance management system and E- HR system for tracking out carbon emission done by both management and employees.

Online Training Programs: Management should provide online training and development programmes for employees regarding environmental and social issues such as waste management, elimination of plastics, creating green products, reducing carbon emission etc.

\section{CONCLUSION}

The green Human assets management has emerged from organizations engaging in practices associated with protection of surroundings and preserving ecological balance. Green HRM encompasses all activities geared toward supporting an agency perform its schedule for surroundings control to reduce its carbon footprint in regions worries on boarding and acquisition of human resources, their induction, performance appraisal \&control, training and development and pay and reward management. Inexperienced HRM can play a beneficial position in enterprise in selling environment related issues by way of adopting and following inexperienced HR guidelines and moves. Green HRM can beautify company image and logo. Inexperienced HR will play an important role in making the employees aware of and worried for protection of natural assets and make contributions in pollutants manipulate, waste control and manufacture of green merchandise.

The proposed technique model will assist the working towards managers and future researchers comply with green HRM strategies. the prevailing study also proposes destiny researchers to fill the space inside the existing literatures by way of accomplishing empirical studies consisting of inexperienced HRM practices within the production or service agencies (mainly the agencies that are polluting surroundings, evaluating green HRM practices among evolved and growing nations, inexperienced perceptions, attitudes of agency and personnel, boundaries within the inexperienced HRM implementation etc. the present look at has made an strive to investigate the notion of employees about the green HRM tasks carried out via the respective businesses. it's been determined that, agencies have been imposing some of inexperienced HRM tasks.

But, more severe method desires to be taken to implement them, communicate them to the employees, encourage employees to stick to such initiatives, and praise them, accurately. Additionally, it's miles vital to include the inexperienced HRM coverage into diverse HRM capabilities, such as, recruitment, induction, education, and so forth. The study also indicates that, employee involvement and participation could play a pivotal role in promoting inexperienced HRM enhancing organizational environmental performance by using focusing on waste control, recycling, maintaining fitness and protection standards, enforcing getting to know from education modules, and selling surroundings friendly organizational culture. Doing so, companies would not directly add fee to their corporate branding, thereby paving the manner for a purifier, more secure, and extra green working surroundings for the personnel and the employer stakeholders. It's far essential to remember the fact that, extra studies need to be carried out to become aware of the world precise environment-control problems. Additionally, there may be a scope for similarly studies to analyze the impact of inexperienced HRM on organizational overall performance. However, the existing take a look at has been capable of become aware of a number of troubles in regard to implementation of green HRM, at workplace in the production industries located in Coimbatore.

\section{REFERENCES}

[1] Brockett, J., Change agents people management, 1-19, 23rd November 2006.

[2] Renwick, D., Redman, T., \& Maquire, S., Green hrm: a review, process model andresearch agenda, Discussion Paper Series, University of Sheffield ManagementSchool, The University of Sheffield, 1-45, 2008.

[3] Smith, E. E., \& Perks, S., A perceptual study of the impact of green practiceimplementation on the business functions, Southern African Business Review, 14(3), 1-29, 2008.

[4] Jacob Cherian, and Jolly Jacob, A study of Green HR Practices and Its Effective Implementation in the Organization, International Journal of Business and Managemnt, 7 (21), 2012.

[5] Mandip, Green HRM: People Management Commitment to Environmental Sustainability, Research Journal Recent Science, 1, 244-252, 2012.

[6] Li Ma, Maolin Ye, The Role of Electronic Human Resource Management in contemporary Human Resource management, Open Journal of Social Sciences, 71-78, 2015.

[7] Prof. Ravi Prasad, Green HRM - Partner in sustainable competitive Growth, Apeejay- Journal of Management science and Technology, $15-18,2015$.

[8] Somaye Nazari, Mir Ali Sayyed Naghavi, A study of Electronics Human Resource Management at the Central Bank and Effectiveness of Human Resources management System, European Journal of Research and Mangement, 290-299, 2015. 